\title{
Characterizing changes in activity and feeding behaviour of housed, lactating dairy cows during behavioural and silent oestrus
}

\author{
by Zebari, H.M., Rutter, S.M. and Bleach, E.C.L.
}

Copyright, Publisher and Additional Information: This is the author accepted manuscript. The final published version (version of record) is available online via Elsevier.

This version is made available under the CC-BY-ND-NC licence:

https://creativecommons.org/licenses/by-nc-nd/4.0/legalcode

Please refer to any applicable terms of use of the publisher

DOI: https://doi.org/10.1016/j.applanim.2018.06.002

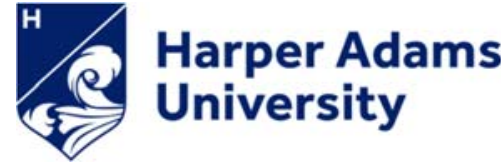

Zebari, H.M., Rutter, S.M. and Bleach, E.C.L. 2018. Characterizing changes in activity and feeding behaviour of housed, lactating dairy cows during behavioural and silent oestrus. Applied Animal Behaviour Science. 
Hawar M. Zebari ${ }^{1,2 *}$, S. Mark Rutter ${ }^{1}$, Emma C.L. Bleach ${ }^{1}$

${ }^{1}$ Department of Animal Production, Welfare and Veterinary Sciences, Harper Adams

5 University, Newport, Shropshire, TF10 8NB, UK

$6{ }^{2}$ Department of Animal Production, College of Agriculture, University of Duhok, Duhok,

7 Kurdistan region, Iraq.

$8 \quad$ *Corresponding author: Hawar M. Zebari

9 Present address: Department of Animal Production, Welfare and Veterinary Science, Harper

10 Adams University, TF10 8NB, UK

11 Mobile number: +447741327862

12 Email address: hzebari@harper-adams.ac.uk

\section{Highlights}

- Activity was increased on the day of behavioural oestrus

- Resting time, lying bouts and feeding behaviours were reduced on the day of behavioural oestrus

21 - Only feeding duration was reduced on the day of silent oestrus 
Abstract

27 The normal time budgets of dairy cows are influenced by oestrus, with cows spending less time resting and eating but more time walking. Previous studies have shown that cows spend approximately $21 \%$ less time feeding where the day of oestrus is assumed to be the day of successful artificial insemination. The objective of the present study was to determine whether

31 the number of steps, lying time, lying bouts, dry matter intake (DMI), feeding duration and the 32 number of visits to feed were affected by behavioural and silent oestrus in lactating dairy cows.

33 Thirty Holstein Friesian cows were housed in a free-stall barn with 34 cubicles and were 34 continuously monitored by four video cameras. Milk samples were collected on Monday, 35 Wednesday and Friday afternoon and analysed for progesterone concentration by enzyme 36 immunoassay. Steps, lying time and lying bouts were measured using IceQubes (IceRobotics 37 Ltd., Edinburgh, UK) from three days before (3DB) to three days after (3DA) oestrus. Daily 38 feed intakes and feeding duration were recorded by a Roughage Intake Control (RIC) system 39 (Insentec B. V., Marknesse, Netherlands) over the same period.

40 Of the 40 behavioural oestrus events, standing behaviour was observed in $50 \%$ of events.

41 On the day of behavioural oestrus the number of steps were increased significantly $(P<0.001)$ 42 compared to 3DB and 3DA oestrus, whilst the percentage of lying time, lying bouts, DMI, 43 feeding duration and the number of visits to feed were reduced $(P<0.001)$ compared to 3DB and 3DA oestrus. On the predicted day of silent oestrus, the duration of feeding was reduced $45(P<0.03)$ only when compared to one day before and one day after oestrus.

46 In conclusion, although the number of steps were increased, lying time, lying bouts, DM 47 intake and feeding duration were reduced by behavioural oestrus, and only feeding duration 48 was significantly lowered during silent oestrus. Technologies that facilitate the on-farm measurement of feeding duration could potentially be used to help farmers detect silent oestrus in their cattle.

52 Keywords: Dairy cows; Time budgets; Behavioural oestrus; Silent oestrus; Activity 


\section{Introduction}

55 The normal time budget of a Holstein dairy cow fed a total mixed ration (TMR) and in freestall housing is 3 to $5 \mathrm{~h} / \mathrm{d}$ eating, with an average 14 feeding bouts per day, 12 to $14 \mathrm{~h} / \mathrm{d}$ lying time, 2 to $3 \mathrm{~h} / \mathrm{d}$ social interaction, 7 to $10 \mathrm{~h} / \mathrm{d}$ rumination during both standing and lying time, $0.5 \mathrm{~h} / \mathrm{d}$ drinking and 2.3 to $3.5 \mathrm{~h} / \mathrm{d}$ spent outside of the yard for milking and other management practices (Grant and Albright, 2000). close to the time of ovulation. Mounting behaviour with standing to be mounted is the definitive sign of oestrus (Roelofs et al., 2010). However, over the past 30 to 50 years, the incidence of mounting behaviour has decreased from $80 \%$ to $50 \%$ in dairy cows (Dobson et al., 2008) and over the last 50 years the duration of oestrus in dairy cattle has also declined from 18 to $8 \mathrm{~h}$ (Dolecheck et al., 2015). Oestrus is the period of maximum sexual activity, it has been shown to range from 2-30 h (Hanzen, 2000). Standing oestrus is often defined as true oestrus, when the cow makes no effort to escape when mounted by other cows and is defined as "the interval between the first and last standing events" (Hurnik et al., 1975). Other signs of oestrus include mounting of other cows, increased activity and mucus discharge from the vulva (Sveberg et al., 2011). While standing to be mounted is considered as the primary behavioural sign of oestrus, other behaviours such as ano-genital sniffing, restlessness, bellowing, chin resting, head mounting, and an attempt to mount are considered secondary signs (Gordon, 2011).

The cows' normal time budget can be influenced by oestrus (Yaniz et al., 2006). During oestrus, the activity of dairy cows increases about 2 to 4 times compared to non-oestrus cows (Kiddy, 1977). In addition, during the period from 72 to $16 \mathrm{~h}$ before standing oestrus, dairy cow activity increases linearly with further increases during the $16 \mathrm{~h}$ before standing oestrus (Arney et al., 1994). In dairy cows ovulation occurs from 8 to $30 \mathrm{~h}$ after the onset of increased activity (Hocky et al., 2010). With the availability of activity monitoring on commercial dairy farms, restlessness has become an important indicator of oestrus (Diskin and Sreenan, 2000).

80 During oestrus, the time spent lying by dairy cows decreased as a result of increased 81 activity and restlessness (Jónsson et al., 2011) driven by increased secretion of oestradiol 
82 (Sumiyoshi et al., 2014) from the developing ovulatory follicle (Allrich, 1994). According to

83 Dolecheck et al. (2015) oestrus-synchronised cows spent less time lying than non-oestrus 84 cows (10.19 vs $24.82 \mathrm{~min} / \mathrm{h}$, respectively) when IceQubes were used to monitor activity and 85 Reith et al. (2014) found that dairy cows drank $15.3 \%$ less water during oestrus. In a study 86 where the day of Al was assumed to be the day of oestrus (rather than observing for oestrus 87 behaviour), Halli et al. (2015) found that cows spent approximately $21 \%$ less time feeding on 88 the day of oestrus in comparison to other days of the oestrous cycle $(2.82 \mathrm{vs} .3 .54 \mathrm{~h} / \mathrm{d}$, 89 respectively), but it was unclear whether the cows were synchronised or naturally cycling. In 90 addition, Reith and Hoy (2012) showed that rumination was reduced on the day of oestrus 91 from 7.2 to $5.9 \mathrm{~h} / \mathrm{d}$.

However, $35 \%$ of cows show no obvious behavioural signs of oestrus and are defined as showing silent oestrus (Palmer et al., 2010). This means that despite the use of oestrus detection aids such as activity monitors, judging the correct time for $\mathrm{Al}$ in naturally cycling cows is difficult. The present study was designed to investigate whether the activity and feeding behaviour of lactating Holstein Friesian cows undergoing spontaneous oestrus cycle

97 is affected by behavioural and silent oestrus.

\section{Materials and methods}

99 The experiment was undertaken between June and August 2016 at the dairy unit of Harper 100 Adams University, Newport, Shropshire, TF10 8NB, UK. The Harper Adams University

101 Research Ethics Committee approved the research protocol.

\subsection{Experimental animal, housing and management}

103 Thirty Holstein-Friesian cows (parity $2.5 \pm 1.1$ ) with initial body weight of $637.0 \pm 60.0 \mathrm{~kg}$ 104 and daily milk yield of $35.8 \pm 1.8 \mathrm{~kg} / \mathrm{d}$, were used at Harper Adams University dairy unit. At the 105 start of the study the cows were $29 \pm 6.3$ days in milk and $2.9 \pm 0.28$ body condition score

106 (Scale 1-5; AHDB Dairy, 2014). The average locomotion score (Scale 1-5; as described by 107 Chapinal et al., 2009) of the selected cows was $2.0 \pm 0.58$. Cows were housed in a covered 
108 yard with 34 cubicles $(2.7 \times 1.2 \mathrm{~m}$, with $3 \mathrm{~cm}$ thick rubber mattresses) and two grooved

109 concrete passageways $(6 \times 50 \mathrm{~m})$ giving approximately $10.8 \mathrm{~m}^{2}$ area per cow. The cubicles

110 were bedded with sawdust three times per week. The passageways were scrapped by an

111 automatic scraper 4-5 times per day. Study cows were milked twice a day from approximately

112 05:00 and 16:30 through a 40-point internal rotary milking parlour (Wesfalia, GEA Milking

113 System, Germany). Milking took approximately 30-40 minutes for the group.

114 Cows were fed from 30 Roughage Intake Control (RIC) system bins and intake recorded

115 using an automated feed recording system $(1.0 \times 0.9 \times 0.8 \mathrm{~m} ; \mathrm{RIC}$, Insentec B. V. Marknesse,

116 the Netherlands). They were moved into the study area on $6^{\text {th }}$ June 2016 and data were

117 collected until $19^{\text {th }}$ August 2016 . All the cows used in the study were trained to feed through

118 RIC bins over a one week period in order to ensure that each cow could access feed without

119 assistance. Approximately $65 \mathrm{~kg}$ (fresh weight) of a total mixed ration (TMR) (see Table 1)

120 was provided daily at approximately 08:30, sufficient for ad libitum availability. Refused feed

121 was removed three times per week on Monday, Wednesday and Friday morning at 08:00 and

122 the RIC bins were cleaned before fresh feed was allocated. Water was provided ad libitum

123 from three water troughs. Feed samples were collected directly from the RIC bins daily at

124 feeding time and immediately oven dried overnight at $105^{\circ} \mathrm{C}$ to constant weight (AOAC, 2012;

125 934.01) for determination of dry matter (DM). The nutrient content of the ration composed of

126 DM (39.5\%), ME (11.8 MJ/kgDM), CP (17.6\% DM) and NDF (36.4\% DM).

\section{2.2. Data collection}

\section{2.2.1. Video recording of oestrus behaviours}

129 The cows were monitored to detect spontaneous behavioural oestrus using four video 130 cameras (Voltek, KT\&C Co Ltd, Seoul, South Korea) for approximately $19.46 \pm 1.7 \mathrm{~h} / \mathrm{d}$. The 131 four cameras were placed at about $5.25 \mathrm{~m}$ above the trial cubicles and passageways to give 132 a clear view of the area in which cows were housed. The cameras were connected to an 133 external hard drive video recorder (Sentient 960H, England, UK). Cows were clearly identified 134 by numbers from 1 to 30 on both sides of the cow and an individual combination of coloured 
135 tape on each cow (Kerbrat and Disenhaus, 2004). Video recordings were retrospectively

136 reviewed to determine the time and intensity of oestrus. The scores of Van Eerdenburg et al.

137 (2002) (Table 2) were allocated and recorded each time a sign of oestrus was observed on

138 the video recording. The total number of points scored in a day indicated oestrus intensity.

139 2.2.2. Cow's activity and feed intake

140 To monitor cow activity, IceQubes (IceRobotics Ltd., Edinburgh, UK) were attached to the 141 back left leg of each cow using a Velcro hook and loop strap (Dolecheck et al., 2015). The 142 IceQube is a 3-axis accelerometer which reports cow activity summarised in 15 minute blocks 143 (Dolecheck et al., 2015). These generate data to show the number of steps taken, lying time 144 and lying bouts for each cow, every day. Daily TMR intake was recorded by the RIC system.

145 Dry matter intake was calculated as TMR intake (fresh weight; kg/d) $\mathrm{x}$ dry matter of TMR. Total 146 daily feeding duration and the number of feeding bouts were also recorded by the RIC system.

\section{2.3. Milk progesterone assay}

148 Oestrus periods were identified by measuring the concentration of progesterone in whole 149 milk. Milk samples $(40 \mathrm{ml})$ were collected from each cow 3 times per week on Monday, 150 Wednesday and Friday afternoon. Immediately after sampling one preservative tablet (Broad 151 Spectrum Microtabs II, Advanced Instrument, INC. USA; containing 8 mg Bronopol and 0.30 $152 \mathrm{mg}$ Natamycin) was added to each milk sample. Sample pots were inverted to mix until the 153 tablet was dissolved. The samples were stored in a refrigerator at $4^{\circ} \mathrm{C}$ until the progesterone 154 assay which was completed within one week of collection. Milk samples were brought to room 155 temperature and mixed well before analysis using an enzyme immunoassay (Ridgeway 156 Science Ltd., Rodmore Mill Farm, Alvington, Gloucestershire, UK). A cow was considered in 157 oestrus when milk progesterone concentrations were $<3 \mathrm{ng} / \mathrm{ml}$ for two to three days before a 158 period when progesterone rose to $>5 \mathrm{ng} / \mathrm{ml}$ for at least 5 days (Isobe et al., 2004). 


\subsection{Definition of behavioural and silent oestrus}

162 Each oestrus identified by the progesterone profile was classified as a behavioural or silent 163 oestrus. A cow was defined to be in behavioural oestrus when the sum of the points scored 164 for oestrus behaviour observed by the video recording exceeded 100 (Van Eerdenburg et al., 165 2002). A cow was considered to be in silent oestrus when the cow did not display any 166 behavioural signs of oestrus or the oestrus score was $<100$ points at or around the day of 167 oestrus as defined by her milk progesterone profile (Van Eerdenburg et al., 2002).

\subsection{Duration of oestrus}

The duration of oestrus recorded by the camera was defined as the interval between the

170 time that cows showed the first signs of oestrus and the time that the last signs of oestrus 171 were observed. Oestrus duration based on accelerometer data was defined as an increase in 172 walking activity and the number of steps taken increased to $>80 \%$ above the mean number 173 for the preceding three days followed by a decrease to $<80 \%$ in the following two days. The 174 periods between the two thresholds was considered as the duration of oestrus (Lopez-Gatius, 175 et al., 2008).

\subsection{Data-set construction}

177 Data from 61 oestrus events were collected during the study period. The six parameters analysed were the number of steps taken by cows each day, time spent lying $(\mathrm{h} / \mathrm{d})$, number of lying bouts per day, DM intake ( $\mathrm{kg} / \mathrm{d})$, feeding duration $(\mathrm{h} / \mathrm{d})$ and number of visits to feed per day. Prior to statistical analysis, the data for all parameters were summarized to one value per

181 day using Microsoft Excel. A day was defined as the period from midnight to midnight. The 182 day of oestrus was defined as day ( 0 ) and compared with three days before $(-3,-2$ and -1 ; 183 3DB) and three days after $(+1,+2$ and +3 ; 3DA). Fresh TMR intakes $(\mathrm{kg} / \mathrm{d})$ intakes were converted into DM intake (kg DM/d) based on the DM content of the TMR (39.5\%). 


\subsection{Statistical analyses}

188 Statistical analyses were performed using the Genstat statistical software package

189 (Genstat V 17 ${ }^{\text {th }}$ edition, VSN international Ltd, UK). The datasets were analysed by repeated measures ANOVA to compare between groups (behavioural and silent oestrus) days before and after oestrus and the group $\mathrm{x}$ day interaction. Factorial one way ANOVA was used to

192 compare behavioural and silent oestrus. Differences were reported as significant at $P<0.05$

193 and trends were reported when $P$ was between $<0.1$ and $>0.05$. Linear regression analysis

194 was used to determine the relationship between the number of steps taken per day and dry

195 matter intake $(\mathrm{kg} \mathrm{DM} / \mathrm{d})$ on the day of behavioural oestrus.

\section{3. Results}

\section{3.1. The duration of oestrus and scores of behavioural activity}

198 Using the milk progesterone profiles, 61 spontaneous oestrus events were detected for all 199 cows during the study period. Of the 61 oestrus events detected, 40 were defined as 200 behavioural (65.5\%) and 21 defined as silent (34.5\%) oestrus. The percentage of silent 201 oestrus at the first, second and third oestrus post-partum were $44.8 \%, 27.3 \%$ and $20.0 \%$ 202 respectively in the present study. The percentage of cows standing to be mounted during 203 behavioural oestrus was 50\%.

204 The average duration of behavioural oestrus (determined from video recordings) was $9.1 \pm$ $2053.1 \mathrm{~h}$ and the duration of oestrus based on the number of steps recorded by lceQubes was $20612.9 \pm 2.5 \mathrm{~h}$. The number of points scored during behavioural oestrus determined from the 207 camera recordings were between 225 and 2921 points. However, during silent oestrus the 208 number of points scored were between 0 and 32 points.

\subsection{Oestrus activity}

210 On the day of behavioural oestrus the number of the steps (2095 \pm 217 steps; mean \pm 211 SEM) were higher $\left(F_{6,354}=32.2, P<0.001\right)$ compared to 3DB (849 \pm 60 steps) and 3DA (971

$212 \pm 61$ steps) while on the day of silent oestrus the number of steps (984 \pm 73.5 steps) were not 213 significantly different in comparison to 3DB ( $891 \pm 63$ steps) and 3DA ( $849 \pm 50$ steps). From 
214 factorial one way ANOVA, cows took significantly more steps during behavioural oestrus $\left(F_{1,39}\right.$

$215=13.2, P<0.001)$ compared to silent oestrus. There was a significant interaction $\left(F_{6,354}=5.6\right.$,

$216 P<0.001)$ between oestrus expression and day of oestrus on the number of steps taken

217 (Figure1, A). In addition, there was a significant $\left(F_{1,39}=31.9, P<0.001\right)$ positive correlation 218 between the number of points scored and the number of steps taken $(y=0.348 x+486 ; P<$ $2190.001 ; r^{2}=0.32$ ) during behavioural oestrus.

220 Lying time and the number of lying bouts $(7.1 \pm 0.3 \mathrm{~h} / \mathrm{d}$ and $9.1 \pm 0.5$ bouts, respectively $)$ 221 were reduced $\left(F_{6,354}=17.2, P<0.001\right)$ on the day of behavioural oestrus in comparison to $2223 \mathrm{DB}(10.0 \pm 0.3 \mathrm{~h} / \mathrm{d}$ and $13.0 \pm 0.7$ bouts, respectively $)$ and $3 \mathrm{DA}(10.1 \pm 0.3 \mathrm{~h} / \mathrm{d}$ and $12.7 \pm 0.8$ 223 bouts, respectively). However, lying times $(9.3 \pm 0.5 \mathrm{~h} / \mathrm{d})$ and the number of lying bouts (13.0 $224 \pm 1.1)$ bouts were not significantly affected by the day of silent oestrus compared to 3DB (10.0 $225 \pm 0.4 \mathrm{~h} / \mathrm{d}$ and $14.0 \pm 1.2$ bouts, respectively) and 3DA $(10.4 \pm 0.4 \mathrm{~h} / \mathrm{d}$ and $13.7 \pm 1.3$ bouts, 226 respectively). Furthermore, from a factorial one way $($ ANOVA $)$, lying times were lower $\left(F_{1,39}=\right.$ $22717.2, P<0.001$ ) on the day of behavioural oestrus compared to silent oestrus and the number 228 of lying bouts were also lower $\left(F_{1,39}=17.2, P<0.001\right)$ on the day of behavioural oestrus 229 compared to silent oestrus. With regard to lying time, there was a significant oestrus $\mathrm{x}$ day 230 interaction $\left(F_{6,354}=5.6, P<0.001\right)$ with lying time significantly reduced during behavioural 231 oestrus but not silent oestrus (Figure 1, B). Similarly, the number of lying bouts was reduced 232 during behavioural oestrus but not during silent oestrus as well as there being an interaction 233 between oestrus expression and day $\left(F_{6,354}=3.3, P<0.006\right)$ (Figure $\left.1, \mathrm{C}\right)$.

\section{3.3. Feeding behaviour}

235 Dry matter intakes were significantly $\left(F_{6,354}=12.0, P<0.001\right)$ lower on the day of 236 behavioural oestrus $(19.8 \pm 0.41 \mathrm{~kg} / \mathrm{d})$ in comparison to 3DB $(22.4 \pm 0.5 \mathrm{~kg} / \mathrm{d})$ and 3DA $(22.6$ $237 \pm 0.5 \mathrm{~kg} / \mathrm{d})$. There was a significant $\left(F_{1,39}=31.9, P<0.001\right)$ negative correlation between the 238 number of steps taken and DMI $\left(y=-0.0014+22.46 ; P<0.001 ; r^{2}=0.46\right)$ during behavioural 239 oestrus. However, DMI was not significantly lower on the day of silent oestrus compared to 240 other days. There was also no interaction between oestrous expression and day (Table 3). 
241 The occurrence of behavioural oestrus significantly $\left(F_{6,354}=9.2, P<0.001\right)$ reduced the

242 mean duration of feeding $(2.4 \pm 0.09 \mathrm{~h} / \mathrm{d})$ in comparison to 3DB $(3.4 \pm 0.17 \mathrm{~h} / \mathrm{d})$ and 3DA (3.2

$243 \pm 0.12 \mathrm{~h} / \mathrm{d})$. Duration of feeding $(2.9 \pm 0.15 \mathrm{~h} / \mathrm{d})$ was also significantly $(P<0.03)$ reduced

244 during silent oestrus when compared to one day before ( $3.4 \pm 0.2 \mathrm{~h} / \mathrm{d})$ and one day after (3.6

$245 \pm 0.2 \mathrm{~h} / \mathrm{d}$ ) the predicted day of oestrus. There was a tendency for an interaction between

246 oestrous expression and day $\left(F_{6,354}=2.1, P=0.06\right)$ effect on feeding duration (Table 3$)$.

247 The mean number of visits to the RIC feed bin during behavioural oestrus was less (25.3

$248 \pm 1.26$ visits $\left./ \mathrm{d} ; F_{6,354}=9.5, P<0.01\right)$ compared with 3DB and 3DA oestrus. However, there

249 were no significant differences between the day of silent oestrus $(29.0 \pm 1.71$ visits/d) in

250 comparison to other days. There was also no significant interaction between oestrus

251 expression and day with regard to the number of visits to feed. Analysing the number of visits

252 to feed with regard to oestrous expression, there was also no significant difference $\left(F_{1,59}=\right.$

$2531.0, P=0.318$ ) between behavioural and silent oestrus (Table 3).

\section{4. Discussion}

\section{4.1. Oestrus duration and observed oestrus activity}

256 Previously, the duration of standing oestrus in dairy cows has been considered to be $18 \mathrm{~h}$

257 (Valenza et al., 2012). The average duration of oestrus measured using the video camera in

258 the present study was $9.1 \pm 3.1 \mathrm{~h}$. However this was 2 hours longer than the duration reported

259 by Sveberg et al. (2011) of $(7.1 \pm 1.4 \mathrm{~h})$ in oestrus detected by video recording of 22 Holstein-

260 Friesian cows housed on an outdoor wood chip-pad. Based on the number of steps recorded

261 by the IceQubes, the duration of oestrus in the present study was $(12.9 \pm 2.5 \mathrm{~h})$ very similar

262 to that seen in the study of Roelofs et al. (2005) which found that the duration of oestrus

263 detected by pedometer lasted for $12.3 \mathrm{~h}$, while a study by Silper et al. (2015), reported longer

264 oestrus in 12 month old Holstein heifers $(14.3 \pm 4.1 \mathrm{~h})$ using neck mounted accelerometers.

265 However, the duration of oestrous activity in the present study was $3.2 \mathrm{~h}$ shorter than that

266 reported by Valenza et al. (2012) of $16.1( \pm 4.7 \mathrm{~h})$ also using an activity monitoring system.

267 The present study found that the duration of oestrus determined by activity monitor was $3 \mathrm{~h}$ 
268 longer than that detected by observation. The difference between the duration of oestrus 269 activity in high yielding dairy cows may be due to the disconnection of secondary signs of 270 oestrus behaviour detected by activity monitors (restlessness) and standing oestrus (Valenza 271 et al. (2012). Our finding is supported by a reported increase in activity, detected by 272 pedometers in dairy cows, 1 to $3 \mathrm{~h}$ before the onset starting of standing oestrus (Sveberg et 273 al., 2011).

274 In the present study, standing behaviour was observed in $50 \%$ of those cows expressing 275 behavioural oestrus. Similarly, Van Eerdenburg et al. (2002) detected $50 \%$ of standing 276 oestrus events in Holstein Frisian cows. However, Kerbrat and Disenhaus (2004) observed 277 standing events by video camera in $32 \%$ of Holstein cows housed in a loose housing system 278 with a concrete floor. The results of the present study indicate that there is great variability 279 between cows in the total points scored with between 225 and 2921 points during behavioural 280 oestrus and the number of steps taken during oestrus (754 to 6008 steps). The results of the 281 current study agree with those reported by Van Eerdenburg et al. (1996) who continuously 282 monitored cows and another study conducted on Holstein cows by Kerbrat and Disenhaus 283 (2004) who reported the total number of behavioural signs (rather than points score) which 284 ranged from 27 to 239 signs. As expected, the oestrus scores of the present study were 285 higher than the scores (approximately 50 -1000 points) reported by Van Eerdenburg et al. 286 (2000) who observed cows during two time periods of about $30 \mathrm{~min}$ in the morning at 5:00 287 before milking and $30 \mathrm{~min}$ in the afternoon at 17:00.

288 In dairy cows, oestrus often takes place without clear changes in behaviour (Kyle et al., 289 1992). Indeed this was the case in $44.8 \%$ of first post-partum oestruses observed in the 290 present study. Low expression of oestrus behaviour at the first oestrus post-partum in 291 lactating dairy cows is thought to be an effect of high concentrations of oestradiol from foetal 292 origin during late gestation, which induces refractoriness of the hypothalamus to oestradiol 293 (Kyle et al., 1992). Other studies suggested this may also be caused by lower frequency of 294 LH pulses as a result of negative energy balance in early lactation (Lucy, 2001) which results 
295 in lower oestradiol synthesis (Butler, 2000; Isobe et al., 2004) by the pre-ovulatory follicle and

296 decreased the sensitivity of the hypothalamus to oestradiol which leads to a high incidence

297 of silent oestrus.

298 4.2. Oestrus activity detected by activity monitor

299 Overall, $65.5 \%$ of the spontaneous oestruses identified in the present study were 300 associated with behavioural signs detected by video recording and the percentage of oestrus 301 detected by accelerometer was $52.5 \%$. This was within the range 51 to $87 \%$ found by Roelofs 302 et al. (2005) using pedometers for oestrus detection. The results of the present study also 303 agree with the previously reported $52 \%$ detection rate in cubicle housed Holstein-Friesian 304 cows studied by Palmer et al. (2010). At-Taras and Spahr (2001) detected approximately $30554 \%$ of oestrus by visual observation. Conversely, this finding was lower than the $70 \%$ of 306 oestrus events detected recorded by Fricke et al. (2014) in oestrus-synchronized Holstein 307 cows using an activity monitor attached to the neck (Heatime, SCR Engineer Ltd, Netanya, 308 Israel). This high detection rate may be related to the high number of cows in oestrus at the 309 same time (Gilmore et al., 2011).

310 Restlessness is one of the most important secondary indicators of oestrus in cattle (Firk 311 et al., 2002). In the current study, on the day of behavioural oestrus, the number of steps was 312 increased by $146.8 \%$, while during silent oestrus, step count was only $10 \%$ higher. Similarly, 313 Sakaguchi et al. (2007) recorded a $100 \%$ increase in the number of steps on the day of 314 behavioural oestrus using radiotelemetric pedometers on grazing dairy Holstein heifers in 315 Japan. Using pedometers, ultrasound and visual observation, Roelofs et al. (2005) recorded 316 a 5.5 fold increase in the number of steps taken on the day of visually observed oestrus.

317 Environmental conditions, the type of housing and management conditions may affect the 318 extent of walking activity (Lopez-Gatius et al., 2005; Yaniz et al., 2006).

319 Alongside the increase in activity, on the day of behavioural oestrus in the present study, 320 cows spent significantly less time lying down (32.2\%) and had $28.3 \%$ fewer lying bouts during 321 spontaneous oestrous events. On the day of behavioural oestrus, continuously observed 
322 Friesian cows housed in cubicles were also found to spend less time lying down

323 (approximately $5 \mathrm{~h} / \mathrm{d}$ ) and more time standing than non-oestrus cows (Esslemont and Bryant, 324 1976).

325 A recent study at the University of Kentucky conducted by Dolecheck et al. (2015) using 326 oestrus-synchronised Holstein cows, found a $50 \%$ decrease in lying time and also a reduction 327 in lying bouts $(56.0 \%)$ during oestrus. The greater reduction in lying behaviour may be 328 because oestrus synchronization meant there are more cows in oestrus at the same time 329 (Hurnik et al., 1975) resulting in greater restlessness and activity on the day of behavioural 330 oestrus (Roelofs et al., 2005; Jónsson et al., 2011).

\section{4.3. Feeding behaviour}

332 In the present study, cows consumed approximately $22 \mathrm{~kg} \mathrm{DMl} / \mathrm{d}$ during a normal days, 333 similar to other published studies of early lactation cows: e.g. Dado and Allen (1994) reported 334 average DMl/d of $22.8 \mathrm{~kg}$ during a normal day. However, on the day of behavioural oestrus, 335 the increase in activity observed was associated with a $12 \%$ reduction in DMI. Furthermore, 336 both feeding duration and the number of visits to feed per day were lower on the day of

337 behavioural oestrus compare to 3DB and 3DA. These data suggest that increased activity at 338 oestrus diverts cows from their normal time budget with more steps replacing both feeding 339 and resting time (Walker et al., 2008). This is exacerbated in more active cows which had a 340 greater reduction in DMI demonstrated by the negative correlation between the number of 341 steps taken and DMI during the day of behavioural oestrus. Other studies of Holstein-Friesian 342 cows have shown reduced DMI on the day of AI (14.6\%; Reith et al., 2014, 10.3\%; Halli et 343 al., 2015). Cows spent a similar amount of time feeding $(2.8 \mathrm{~h} / \mathrm{d})$ but had many more visits to 344 the feed troughs (46.2 visits/d) than in the present study (Halli et al., 2015). This may be 345 because Halli et al. (2015) only determined feeding behaviours in relation to Al rather than 346 behavioural oestrus.

347 As far as we are aware, the present study is the first to report feeding behaviour during 348 silent oestrus in dairy cows. Interestingly, while behavioural measures were not changed 
during the predicted time of silent oestrus in the current study, DMI and number of visits to

350 the RIC bins were numerically lower in comparison to 3DB and 3DA oestrus. In addition

351 feeding duration was significantly reduced compared to one day before and one day after

352 oestrus. This finding indicates that cows deemed in silent oestrus may show subtle changes

353 to their behavioural repertoire that are not apparent using commercial oestrus detection

354 regimes. Alternatively, oestradiol has been shown to suppress feed intake (Ingvartsen and

355 Andersen, 2000) and an increase in oestradiol concentration at silent oestrus may be

356 sufficient to reduce feed intake but not sufficiently adequate to increase oestrus activity. On

357 the day of oestrus, the higher physical activity and restlessness in dairy cows may replace

358 feeding behaviour (DMI, feeding duration and number of visits to feed) (Hurnik et al., 1975;

359 Kiddy, 1977). In the present study there was a negative relationship between the number of

360 steps and DMI. In comparison to non-oestrus cows, during oestrus, cows spent more time

361 walking and consequently less time resting and eating (Hurnik et al., 1975). Conversely,

362 Lukas et al. (2008) found that cows consumed more feed on the day of oestrus, while De

363 Silva et al. (1981) reported no change in feed intake on the day oestrus.

\section{5. Conclusion}

365 During the day of behavioural oestrus, high yielding dairy cows in cubicle housing spend 366 more time walking, less time lying down and a reduced number of lying bouts, but none of 367 these parameters were affected during silent oestrus. In addition, on the day of behavioural 368 oestrus, DM intake, feeding duration and number of visits to feed were reduced. On the day 369 of silent oestrus, only feeding duration was reduced. Technologies that facilitate the on-farm 370 measurement of feeding duration could potentially be used to help farmers detect silent 371 oestrus in their cattle. Where behavioural oestrus is expressed there is considerable variation 372 in the extent of activity, but the reasons for this remain to be elucidated. It remains to be 373 determined why these differences are seen but one factor worthy of investigation maybe 374 circulating oestradiol concentrations. 
377 The study was financially supported by HCED-Iraq. Special thanks are due to the HAU 378 farm staff and technicians (Carrie Gauld and Sarah Williams) for their assistance.

\section{6. Referenes}

380 AHDB 2014. Body condition scoring. [Online] Accessed online at 07-03-2014.

381 (https://dairy.ahdb.org.uk/resources-library/technical-information/health-welfare/body-condition-

382 scoring/\#.Wqach-jFKUk).

383 Allrich, R.D., 1994. Endocrine and neural control of estrus in dairy cows. J Dairy Sci 77, 27383842744.

385 Arney, D.R., Kitwood, S.E. and Phillips, C.J.C., 1994. The increase in activity during oestrus 386 in dairy cows. Appl Anim Behav Sci 40, 211-218.

387 At-Taras, E.E. and Spahr, S.L., 2001. Detection and characterization of estrus in dairy cattle 388 with an electronic heat mount detector and an electronic activity tag. J Dairy Sci 84, 792-798. 389 Butler, W.R., 2000. Nutritional interactions with reproductive performance in dairy cattle. Anim 390 Reprod Sci 60, 449-457.

391 Chapinal, N., De Passille, A.M., Weary, D., Von Keyserlingk, M., and Rushen, J. 2009. Using

392 gait score, walking speed, and lying behaviour to detect hoof lesions in dairy cows. J Dary Sci $39392,4365-4374$.

394 Dado, R.G. and Allen, M.S., 1994. Variation in and relationships among feeding, chewing, and 395 drinking variables for lactating dairy cows. J Dairy Sci 77, 132-144.

396 De Silva, A.W., Anderson, G.W., Gwazdauskas, F.C., McGilliard, M.L., Lineweaver J.A., 1981. 397 Interrelationships with estrous behavior and conception in dairy cattle. J Dairy Sci 64, 24093982418.

399 Diskin, M.G. and Sreenan, J.M., 2000. Expression and detection of oestrus in cattle. Reprod $400 \quad$ Nut Devel 40, 481-491.

401 Dobson, H., Walker, S.L., Morris, M.J., Routly, J.E. and Smith, R.F., 2008. Why is it getting 402 more difficult to successfully artificially inseminate dairy cows?. Animal 8, 1104-1111. 
403 Dolecheck, K.A., Silvia, W.J., Heersche, G., Chang, Y.M., Ray, D.L., Stone, A.E., and Bewley,

404 J.M., 2015. Behavioural and physiological changes around estrus events identified using 405 multiple automated monitoring technologies. J Dairy Sci 98, 8723-8731.

406 Esslemont, R.J. and Bryant, M.J., 1976. Oestrous behaviour in a herd of dairy cows. Vet Repo $40799,472-475$.

408 Firk, R., Stamer, E., Junge, W. and Krieter, J., 2002. Automation of oestrus detection in dairy 409 cows: a review Livest Prod Sci 75, 219-232.

410 Fricke, P.M., Carvalho, P.D., Giordano, J.O., Valenza, A., Lopes, G., and Amundson, M.C. 4112014 . Expression and detection of estrus in dairy cows: the role of new technologies. Animal 8 , $412 \quad 134-143$.

413 Gilmore, H.S., Young, F.J., Patterson, D.C., Wylie, A.R.G., Law, R.A., Kilpatrick, D.J., Elliott, 414 C.T. and Mayne, C.S., 2011. An evaluation of the effect of altering nutrition and nutritional 415 strategies in early lactation on reproductive performance and estrous behavior of high-yielding 416 Holstein-Friesian dairy cows. J Dairy Sci 94, 3510-3526.

417 Gordon, P. 2011. Oestrus detection in dairy cattle. In Practice 33, 542-546.

418 Grant, R.J., and Albright, J.L., 2000. Feeding behaviour. In Farm Animal Metabolism and 419 Nutrition. J.P.F. D'Mello, ed. CABI Publishing. New York, NY.

420 Halli, K., Koch, C., Romberg, F.J. and Hoy, S., 2015. Investigations on automatically measured 421 feed intake amount in dairy cows during the oestrus period. Archiv Tierz, 58, 93.

422 Hanzen, C.H., Pieterse, M., Scenczi, O. and Drost, M., 2000. Relative accuracy of the 423 identification of ovarian structures in the cow by ultrasonography and palpation per 424 rectum. The Veterinary J 159, 161-170.

425 Hockey, C.D., Morton, J.M., Norman, S.T. and McGowan, M.R., 2010. Evaluation of a neck 426 mounted 2-hourly activity meter system for detecting cows about to ovulate in two paddock427 based Australian dairy herds. Repro in Domestic Anim 45, 107-117.

428 Hurnik, J.F., King, G.J. and Robertson, H.A., 1975. Estrous and related behaviour in 429 postpartum Holstein cows. Appl. Anim. Etho 2, 55-68. 
430 Ingvartsen, K.L. and Andersen, J.B., 2000. Symposium: Dry matter intake of lactating dairy

431 cattle. J Dairy Sci 83, 1573-1597.

432 Isobe, N., Yoshimura, T., Yoshida, C. and Nakao, T., 2004. Incidence of silent ovulation in 433 dairy cows during post-partum period. DTW De Tie 111, 35-38.

434 Jónsson, R., Blanke, M., Poulsen, N.K., Caponetti, F. and Højsgaard, S., 2011. Oestrus 435 detection in dairy cows from activity and lying data using on-line individual models. Comp Elect 436 Agri 76, 6-15.

437 Kerbrat, S. and Disenhaus, C., 2004. A proposition for an updated behavioural 438 characterisation of the oestrus period in dairy cows. Appl. Anim Behav Sci 87, 223-238.

439 Kiddy, C.A., 1977. Variation in physical activity as an indication of estrus in dairy cows. J Dairy 440 Sci 60, 235-243.

441 Kyle, S.D., Callahan, C.J. and Allrich, R.D., 1992. Effect of progesterone on the expression of 442 estrus at the first postpartum ovulation in dairy cattle1. J Dairy Sci 75, 1456-1460.

443 López-Gatius, F., Santolaria, P., Mundet, I. and Yániz, J.L., 2005. Walking activity at estrus 444 and subsequent fertility in dairy cows. Theriogenol 63, 1419-1429.

445 Lucy, M.C., 2001. Reproductive loss in high-producing dairy cattle: where will it end?. J Dairy 446 Sci 84, 1277-1293.

447 Lukas, J.M., Reneau J.K., Linn J.G., 2008. Water intake and dry matter intake changes as a 448 feeding management tool and indicator of health and estrus status in dairy cows. J Dairy Sci $44991,3385-94$.

450 Palmer, M.A., Olmos, G., Boyle, L.A. and Mee, J.F., 2010. Estrus detection and estrus 451 characteristics in housed and pastured Holstein-Friesian cows. Theriogenol 74, 255-264.

452 Reith, S. and Hoy, S., 2012. Relationship between daily rumination time and estrus of dairy 453 cows. J Dairy Sci 95, 6416-6420.

454 Reith, S., Pries, M., Verhülsdonk, C., Brandt, H. and Hoy, S., 2014. Influence of estrus on dry 455 matter intake, water intake and BW of dairy cows. Animal 8, 748.

456 Roelofs, J., Lopez-Gatius, F., Hunter, R.H.F., Van Eerdenburg, F.J.C.M. and Hanzen, C., 457 2010. When is a cow in estrus? Clinical and practical aspects. Theriogenol $74,327-344$. 
458 Roelofs, J.B., van Eerdenburg, F.J., Soede, N.M. and Kemp, B., 2005. Pedometer readings

459 for estrous detection and as predictor for time of ovulation in dairy cattle. Theriogenol 64, $460 \quad 1690-1703$.

461 Sakaguchi, M., Fujiki, R., Yabuuchi, K., Takahashi, Y. and Aoki, M., 2007. Reliability of estrous 462 detection in Holstein heifers using a radiotelemetric pedometer located on the neck or legs 463 under different rearing conditions. J Reprod Devel 53, 819-828.

464 Schwarz, F. J., 2008. Concentration and intake amount of nutrients in lactating dairy cows/feed 465 intake. Guide to the study, advice and practice, $12^{\text {th }}$ ed., Frankfurt am Main, Germany, 366466372.

467 Silper, B.F., Madureira, A.M.L., Kaur, M., Burnett, T.A. and Cerri, R.L.A., 2015. Short 468 communication: Comparison of estrus characteristics in Holstein heifers by 2 activity 469 monitoring systems. J Dairy Sci 98, 3158-3165.

470 Sumiyoshi, T., Tanaka, T. and Kamomae, H., 2014. Relationships between the appearances 471 and changes of estrous signs and the sstradiol-17 $\beta$ peak, luteinizing hormone surge and 472 ovulation during the periovulatory period in lactating dairy cows kept in tie-stalls. J Reprod 473 Devel 60, 106-114.

474 Sveberg, G., Refsdal, A., Erhard, H., Kommisrud, Aldrin, M., Tvete, I. and Ropstad, E.2011. 475 Behaviour of lactating Holstein-Friesian cows during spontaneous cycles of estrus. J Dairy 476 Sci 94, 1289-1301.

477 Valenza, A., Giordano, J.O., Lopes, G., Vincenti, L., Amundson, M.C. and Fricke, P.M., 2012. 478 Assessment of an accelerometer system for detection of estrus and treatment with 479 gonadotropin-releasing hormone at the time of insemination in lactating dairy cows. J Dairy $480 \quad$ Sci 95, 7115-7127.

481 Van Eerdenburg, F.J.C.M., Karthaus, D., Taverne, M.A.M., Mercis, I. and Szenci, O., 2002. 482 The relationship between estrous behavioural score and time of ovulation in dairy cattle. J 483 Dairy Sci 85, 1150-1156.

484 Van Eerdenburg, F.J.C.M., Loeffler, H.S.H. and Van Vliet, J.H., 1996. Detection of oestrus in 485 dairy cows: a new approach to an old problem. Veterinary Quarterly 18, 52-54. 
486 Yániz, J.L., Santolaria, P., Giribet, A. and López-Gatius, F., 2006. Factors affecting walking 487 activity at estrus during postpartum period and subsequent fertility in dairy 488 cows. Theriogenol 66, 1943-1950.

489

490

491

492

493

494

495

496

497

498

499

500

501

502

503

504

505

506

507

508

509

510

511

512

513 
514 Table 1. Dietary composition of the trial ration.

\begin{tabular}{|l|c|c|}
\hline Ingredient & g/kg DM & kg DM/hd \\
\hline Maize silage & 342.2 & 7.2 \\
\hline Lucerne & 161.60 & 3.4 \\
\hline Blend & 200.57 & 4.22 \\
\hline Soda wheat & 113.12 & 2.38 \\
\hline Sweet starch & 73.19 & 1.54 \\
\hline Soya hulls & 53.23 & 1.12 \\
\hline Spey syrup & 26.62 & 0.56 \\
\hline Megalac & 7.13 & 0.15 \\
\hline Butterfat extra & 7.13 & 0.15 \\
\hline Dairy minerals & 7.13 & 0.15 \\
\hline Salt & 3.33 & 0.07 \\
\hline Acid buff & 3.80 & 0.08 \\
\hline Saccharomyces cerevisiae & 0.95 & 0.02 \\
\hline Total & 1000 & 21.04 \\
\hline
\end{tabular}

515 (Profeed Nutrition Consultancy, UK, 2016)

516

517

518

519

520

521

522

523

524

525

526 
527 Table 2. Scoring scale for observed signs of oestrous.

\begin{tabular}{|l|c|}
\hline Oestrous signs & Score \\
\hline Flehmen & 3 \\
\hline Mucous discharge from vulva & 5 \\
\hline Cow restlessness & 10 \\
\hline Sniffing the vulva of another cow & 10 \\
\hline Mounting but not standing & 15 \\
\hline Resting the chin on the back of another cow & 35 \\
\hline Mounting or attempt to mount other cows & 45 \\
\hline Mounting or attempt to mount head side other cows & 100 \\
\hline Standing heat & \\
\hline
\end{tabular}

528 Van Eerdenburg et al., 2002.

529

530

531

532

533

534

535

536

537

538

539 
540 Table 3. Means of dry matter intake $(\mathrm{gkDM} / \mathrm{d})$, feeding duration $(\mathrm{h} / \mathrm{d})$ and the number of

541 visiting to feed/d, 3 days before, on the day of oestrus (0) and 3 days after oestrus, during

542 behavioural $(n=40)$ and silent $(n=21)$ oestrus.

\begin{tabular}{|c|c|c|c|c|c|c|c|c|c|c|c|c|}
\hline \multirow[b]{2}{*}{$\begin{array}{c}\text { Feeding } \\
\text { behaviour }\end{array}$} & \multirow[b]{2}{*}{$\begin{array}{l}\text { Oe } \\
\text { EX }\end{array}$} & \multicolumn{7}{|c|}{ Time/Day } & \multirow[b]{2}{*}{ SED } & \multicolumn{3}{|c|}{ P-value } \\
\hline & & -3 & -2 & -1 & 0 & $1+$ & $2+$ & $3+$ & & $\begin{array}{l}\text { Oe } \\
\text { Ex }\end{array}$ & Days & $\begin{array}{c}\text { Oe } \\
\text { Ex } \\
\text { vs. } \\
\text { days }\end{array}$ \\
\hline \multirow{2}{*}{$\begin{array}{l}\text { Dry } \\
\text { matter } \\
\text { intake } \\
\mathrm{kg} / \mathrm{d}\end{array}$} & B & 22.5 & 22.1 & 22.5 & 19.8 & 22.5 & 22.5 & 22.7 & \multirow{2}{*}{0.906} & \multirow{2}{*}{0.314} & \multirow{2}{*}{$<0.001$} & \multirow{2}{*}{0.371} \\
\hline & $S$ & 21.9 & 21.8 & 21.6 & 20.5 & 21.8 & 21.8 & 22.0 & & & & \\
\hline \multirow{2}{*}{$\begin{array}{c}\text { Feeding } \\
\text { duration } \\
\mathrm{h} / \mathrm{d}\end{array}$} & B & 3.5 & 3.4 & 3.3 & 2.4 & 3.2 & 3.2 & 3.3 & \multirow{2}{*}{0.180} & \multirow{2}{*}{0.306} & \multirow{2}{*}{$<0.001$} & \multirow{2}{*}{0.06} \\
\hline & $S$ & 3.1 & 3.4 & 3.4 & 2.9 & 3.6 & 3.4 & 3.4 & & & & \\
\hline \multirow{2}{*}{$\begin{array}{l}\text { Number } \\
\text { of visits } \\
\text { to feed/d }\end{array}$} & B & 29.2 & 28.8 & 27.2 & 25.3 & 27.8 & 28.3 & 28.3 & \multirow{2}{*}{3.754} & \multirow{2}{*}{0.318} & \multirow{2}{*}{$<0.01$} & \multirow{2}{*}{0.588} \\
\hline & $S$ & 29.6 & 29.9 & 29 & 27.1 & 30.5 & 30.6 & 30.8 & & & & \\
\hline
\end{tabular}

543 Oe Ex = Oestrus Expression, B = Behavioural oestrous and S = Silent oestrus, $0=$ day of

544 oestrus, SED = standard errors of differences

545

546

547

548

549

550

551

552 
(A)

554

555

556

557

558

559

(C)

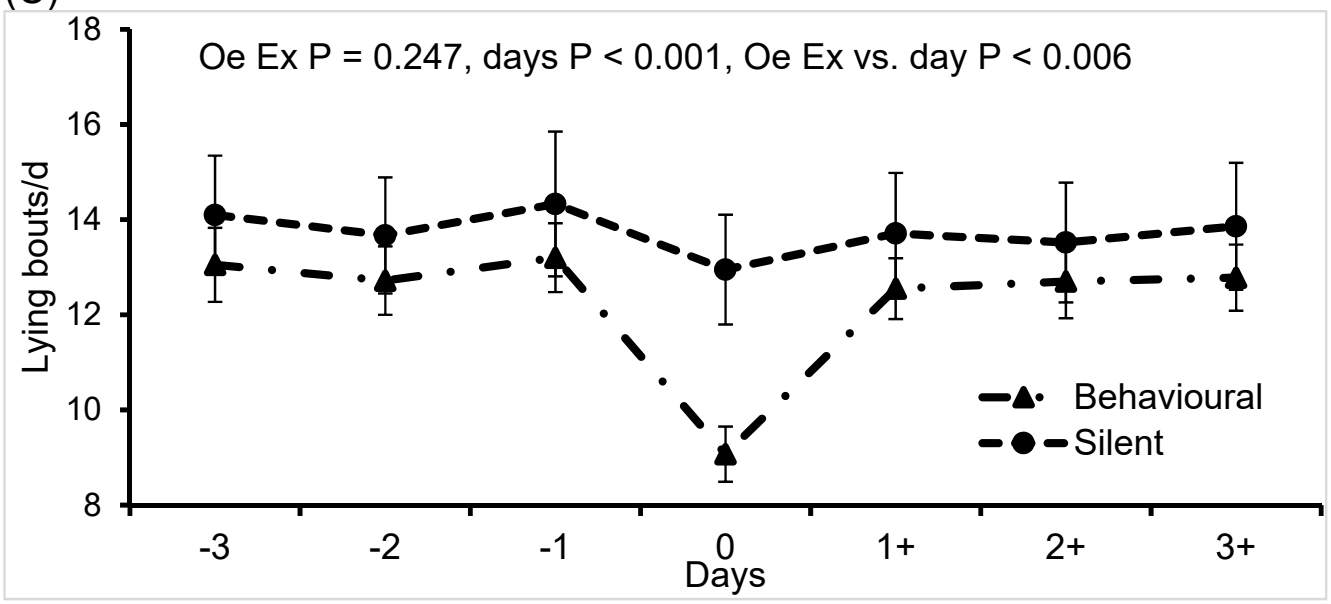

560 Figure 1. Effect of oestrus on number of steps (A), lying time (B) and number of lying bouts

561 (C), 3 days before, on day of oestrus ( 0$)$ and 3 days after and during silent $(n=21)$ and

562 behavioural $(n=40)$ oestrus. Oe Ex $=$ Oestrus Expression, $0=$ day of oestrus. 